\title{
UNRAVELING THE POWER OF TEACHERS' COMPETENCY AND TEACHING STYLES IN CURRICULUM IMPLEMENTATION: A PERSPECTIVE OF ENGLISH LANGUAGE AS A MEDIUM OF INSTRUCTION
}

\author{
Anne Nipher Olieba ${ }^{1 i}$, \\ Ronald Kikechi ${ }^{2}$ \\ ${ }^{1}$ Mount Kenya University, \\ School of Education, \\ Kenya \\ ${ }^{2}$ Dr., Mount Kenya University, \\ School of Education, \\ Kenya
}

\begin{abstract}
:
The language policy in Rwanda states that English is the medium of Instruction (MOI) to be used in the Education system following the 2008 Language shift. However, this change in the MOI brought about extreme challenges to both Rwandan teachers and learners. Moreover, the extensive day to day usage of Kinyarwanda, the local dialect, has greatly inhibited the use of English. This has adversely obstructed the use of the English language as a MOI and the curriculum implementation for over 20 years hence adversely affecting the teaching and learning process. The proficiency of the teachers who are meant to teach in the MOI is quite questionable; many realize the need to learn English while teaching or risk unemployment. As such, this study purposed to examine the teacher competency and teaching styles in use of English as a MOI in facilitating curriculum implementation in rural primary schools in Rwanda. Guided by the inter language theory and the Discrepancy theory, the study applied a descriptive survey research design. With a target population of 3,269, the study entailed a sample of 1470 randomly selected learners from Primary 4 to Primary 6, teachers and head teachers from 21 schools. The study used questionnaires, interviews, and observation to collect primary data. The study found that the teachers' competency in using English language as MOI had significant influence on curriculum implementation in rural primary schools in Muhanga district and in the entire republic of Rwanda. The teaching styles factors positively and significantly influence the use of MOI in curriculum implementation when other factors are held constant.
\end{abstract}

Keywords: English language, medium of instruction, teacher competency, teaching style

${ }^{i}$ Correspondence: email favoredanneolieba@gmail.com 


\section{Introduction}

English language began to spread in the colonized parts of the world and became more evident after World War II due to socio-political and economic factors that affected the society. It has thus continued to dominate even in non-colonized parts of the world and has ultimately developed as a worldwide lingua franca (Holmes, 1997). The language has also integrated more into the education system all over the world. As such, the widespread use of English coerces countries to revise policies about language in their education system. Nevertheless, Evans (2002) evidence that the political and social reformation after political independence from the British and U.S colonies increased the usage of English as a medium of instruction (MOI).

Inferring from Stoller (2008), policymakers, curriculum designers, program planners, teacher educators, teacher supervisors, teachers, material writers and learners still face the challenge of integrating content and language-learning objectives. Historically, the language education policy and practice across Africa has been in distress until recently whereby a series of studies have been developed to offer valuable new insights that assist policymakers and implementation officials (Brock-Utne et al., 2005). Imperatively, the medium of instruction in primary education, as outlined in the language education policy chiefly determines whether there is optimized access to the content of the curriculum or whether it prevents both access and equity to learners (Hornberger, 2008).

A majority of the African governments perceive that their countries have more complex and diverse language education issues when contrasted to others. However, each society is rich linguistically, and the cultural diversity is often ignored or even denied by its education system (Benson, 2012). Nevertheless, each country must find specific solutions to their challenges despite the possibility to learn from countries that appear to have similar challenges, since all societies have varying circumstances.

Considering the case of three East Africa countries Kenya with 42 languages, Uganda 32, and Tanzania with more than 100 languages. Sahle (2015) outlines how the linguistic diversity poses a challenge to formal education. The colonial era introduced formal education but has so far been challenged by the medium of instruction in schools regarding the numerous local dialects. As such, many debates have risen over this issue, such as the education language policy examination debates in the aforementioned countries with considerations to the globalization context, as Sahle (2015) argues. Being neighbors, these three countries share a similar history, including being colonized by the British. However, Tanzania was colonized by the Germans for a short period, before the British took over.

Sibomana (2010) posits that English language as a MOI in Rwanda is still far from satisfactory. He cites Kagire (2008) who argues that the English proficiency of teachers and many educated people in Rwanda remains questionable. Resultantly, the English language is barely used in Rwandan's everyday communication. Bennell and Akyeampong (2007) on the other hand argue that typical rural Rwandan teachers and 
learners still use English exclusively for the classroom. They solely use Kinyarwanda at home, in the streets and with friends.

There are hardly any TV programs, street signs, newspapers and even dialogues held in English in the rural setting. Factors such as poverty levels, inadequate learning and teaching resources, teacher, learner and parental attitudes, environment and most importantly, lack of English proficiency teachers has made it impossible to comply with the policy change and curriculum implementation fully. Pearson (2014) notes that teachers tasked with teaching in English are untrained and unqualified and more often than not only have some years of secondary education, mostly up to school certificate level.

Lastly, conversational skill in a second language does not equate to the academic literacy which is more important but takes much longer to develop. Without serious infrastructure, teacher training, educational materials, supervision and teacher support by head teachers and other education officers, schools fall short of the requirements to add English as a MOI. As such, the quality of education relies on; teachers' qualifications, teaching styles, availability of learning resources, teachers' motivation, planning, management, and administration, at any educational level (Samuelson, 2012).

While several aspects contribute to the varied challenges in implementing the MOI Policy, few researchers in Rwanda have tried to investigate this problem. As such, it is imperative that these challenges in addition to those which have not been mentioned be addressed and subsequently overcome to achieve a successful instructional language move in Rwanda's schools. Therefore, the research steered towards assessing the use of English language as a medium of instruction and curriculum implementation in rural primary schools in Muhanga district.

\section{Literature Review}

\subsection{Teacher Competence in Use of English as a Medium of Instruction}

In the teaching profession, new teachers and head teachers are subjected to many years of experience that are imperative for gaining the skills needed for effectively performing their roles. The complexity of teaching is so great that even experienced teachers are confronted with great challenges each year including changed laws and procedures, new instructional methods, changes in subject content, advanced technology and students' learning needs, posits Mizell (2010) who is cited by Harerimana (2013). As such, Harerimana (2013) continues to evidence that educators with limited professional development opportunities are less likely to better their skills.

Similarly, Lynd (2010) conducted a survey in 2009 under the British Council to which he identified teachers as the weakest chain link in the language implementation policy in Rwanda. Deducing from the outcomes, teachers, therefore, hinder the general progress of the quality of education in the country. Moreover, this survey indicates that many Rwandan teachers lack intermediate level of English proficiency since $85 \%$ of the primary school teachers had only beginner or elementary proficiency. From this, it is 
evident that these same teachers who lack the competency of using the language are responsible for teaching with this $\mathrm{MOI}$.

Additionally, many teachers are seen to having insufficient classroom experience. A survey by MINEDUC (Republic of Rwanda, MINEDUC, 2009) evidenced that a shocking $40 \%$ of teachers from both primary and secondary schools had less than 5 years of teaching experience. Imperatively, it is these same teachers who are directly tasked with facilitating the teaching and learning process, evidencing how their quality, measured by task qualification and dedication, is directly proportional to the academic performance of learners. Therefore, it is vital to understand that most elements of classroom learning involve the teacher, and as such, they must be competent in their duties.

Teachers are the main drivers of curriculum implementation where they are to use English as a MOI and therefore need to have the language competence. This measure of competence in language involves two major categories: 1. Grammar/system division and 2. Conceptual division. According to Thomas (1987), there are possibly four components of pedagogic competence which are (1) Management, which includes classroom management skills. (2) Teaching pedagogic skills involved in using various languages with learners. (3) Preparation; skills involved in preparing for teaching and (4) Assessment; teachers' ability to assess their performance of the various skills mentioned. It is therefore important that a teacher using English, as a MOI, depicts the most effective skills in the use of English language. One can only ascertain the disadvantaging of the young learners, as it is known to all that the most challenging age of learning the language is between 04-05 years (Pearson, 2012).

There is a simple logic that, if all the teachers who the learners interact with are fluent in English language, then the learners easily grasp the language. On the contrary, if a non-English teacher teaches and communicates in mother tongue (as most teachers in rural areas in Rwanda do), lessons taught in English proved ineffective. Therefore, the role of the teachers becomes critical in the whole learning process especially in the rural regions (Samuelson, 2012). This compulsory subject and its requirement to study through it, however, do not strongly motivate the teachers and learners in rural primary schools of Rwanda (Rosendal, 2009).

\subsection{Teaching Styles in Use of English as a Medium of Instruction}

Benson (2012) posits that the effect of instructing in English Language as the MOI can be unfavorable for teachers since they are required to have varying methods and strategies while executing the curriculum. Otaala (2001) argues that these methods and strategies should consequently be assessed across different aspects such as learning and teaching activities, the role of instructional materials and procedures. However, teachers in rural Primary schools in Rwanda have limited proficiency in using the MOI when instructing. Consequently, they fail at varying their word choice or phrasing, or effect teaching methods other than didactic strategies and rote learning. These teachers also applied teaching strategies which included code-switching. 
Rote learning which Mayer (2002) explains as a form of memorization, where the learner can only remember the concept but can hardly apply it in any situation or for problem solving skills. Moreover, teachers also utilize "safe talk" to engage with learners whereby they ask simple yes/no questions and resultantly feed them with answers. This scenario provides limited participatory engagement with learners as it hinders the facilitation of improvised learning where teachers have to creatively step away from the script. This is attributed to the fact that the learners lack the language proficiency to engage in such lessons as suggested by Benson (2012) who deduces from Hornberger. Ellis (2001) describes interference as a transfer which he explains as "influence that the learner's L1 exerts over the acquisition of an L2". His argument is based on the reasoning that a learner's perception of what is transferable in L2 learning is governed by the learner.

In the context under study, use of English language as a MOI and curriculum implementation, the MT, which is Kinyarwanda, is limited to the teaching and learning process. Therefore, Cummings (1964) deduces that language known and encountered in life by a child is the MT. Consequently, elementary schooling in a foreign language epitomizes a grave exit from the essential learning concept that best and effective situation is where learners come from known-unknown. As such, it is the MT, Kinyarwanda in this case, which can acquaint the learners with the concept of abstracts owing to its link to their environment and familiarities. Conclusively, Cumming (2000) argues that mother tongue interference impedes the advancement in speaking, reading, and writing since the patterns of MT hardly match with those of the target language.

\section{Material and Methods}

The researcher applied the inter language theory, supported by the Discrepancy theory. This research applied a descriptive survey research design whereby twenty-one primary schools were randomly selected. The target population comprised of 3,269 persons. A sample size of 1470 was estimated using the Krejcie \& Morgan (1970) sampling tables. The study randomly selected learners from Primary 4 to Primary 6, teachers and head teachers from 21 schools. A pilot study was conducted in 3 target school with similar characteristics for validity and reliability purposes. The researcher used questionnaires, interviews, and observation to collect primary data. Data was cleaned, coded, and analyzed using statistical package for social sciences (SPSS) version 20.

\section{Results and Discussion}

\subsection{Language Used by Subject Teachers during their Lessons}

These results show that out of 189 teachers observed that English medium of instruction was widely used by teachers in the school environment, this argument was clearly substantiated by distribution of their means as illustrated in Table 1. 
Table 1: Language Used by Subject Teachers during their Lessons

\begin{tabular}{|c|c|c|c|c|c|c|}
\hline Statements & & $\begin{array}{l}\text { Kinyarwanda } \\
\text { (5) }\end{array}$ & $\begin{array}{l}\text { English } \\
\text { (4) }\end{array}$ & $\begin{array}{l}\text { Kiswahili } \\
\text { (3) }\end{array}$ & $\begin{array}{l}\text { Others } \\
\text { (2) }\end{array}$ & Mean \\
\hline \multirow{2}{*}{$\begin{array}{l}\text { What language does your } \\
\text { teacher use when teaching } \\
\text { English lesson? }\end{array}$} & Freq. & 107 & 767 & 15 & 21 & \multirow[b]{2}{*}{4.92} \\
\hline & $(\%)$ & 11.8 & 84.3 & 1.6 & 2.3 & \\
\hline \multirow{2}{*}{$\begin{array}{l}\text { What language do the other } \\
\text { subject teachers use while } \\
\text { teaching? }\end{array}$} & Freq. & 204 & 689 & 17 & 0 & \multirow{2}{*}{4.89} \\
\hline & $(\%)$ & 22.4 & 75.7 & 1.9 & 0 & \\
\hline \multirow{2}{*}{$\begin{array}{l}\text { What language do you use } \\
\text { when outside the class? }\end{array}$} & Freq. & 513 & 208 & 80 & 109 & \multirow{2}{*}{3.86} \\
\hline & $(\%)$ & 56.4 & 22.9 & 8.9 & 12 & \\
\hline \multirow{2}{*}{$\begin{array}{l}\text { What language is used to } \\
\text { write exam questions? }\end{array}$} & Freq. & 0 & 910 & 0 & 0 & \multirow{2}{*}{4.97} \\
\hline & $(\%)$ & 0 & 100 & 0 & 0 & \\
\hline Std dev & & .450 & .512 & .372 & .414 & \\
\hline
\end{tabular}

The choice of English as language used to write exams was ranked first with a mean of 4.97, Teaching English lesson using MOI was ranked second with a mean of 4.92. MOI being used by other subject teachers was rank third with a mean of 4.89. However, the use of English out of class was ranked last with a mean of 3.86. From the table, the closeness of deviation from the mean reveals that even though English medium of instruction is largely embraced, the use of other languages interchangeably with MOI during their lessons is significantly felt. Kinyarwanda had a standard deviation of .450, English had .512, and Kiswahili had .372 while other local languages had a deviation of .414. For primary 4-6 classes, the observation also shows that most of the teachers used the MOI, and code mixing/switching, which is also a deviation from the Rwanda's language of instruction policy for primary 4 and upper classes. It is also evident from the data that the pattern of the MOI used cuts across the various subjects taught in the schools involved in this study.

\subsection{View of English as Medium of Instruction by Teachers while Teaching}

The study intended to obtain information on perception and attitude of educators and learners towards the use of MOI in teaching all other subject including English lessons. To identify their perceptions and attitude in consideration of the importance of the feelings listed, a likert-scale type of question was used for answering where 5 represents Strongly Agree, 4 represents Agree, 3 Represents Neutral, 2 represents Disagree and 1 represents Strongly Disagree. Hence, the mean and standard deviation were used in measuring this variable. The variables measured here was, If MOI was boring, interesting, alright, very interesting or very boring. This is illustrated in Table 2. 
Table 2: View of English as Medium of Instruction by Teachers

\begin{tabular}{|c|c|c|c|c|c|c|c|c|}
\hline Statements & & $\begin{array}{l}\text { Strongly } \\
\text { agree (5) }\end{array}$ & $\begin{array}{c}\text { Agree } \\
(4)\end{array}$ & $\begin{array}{c}\text { Neutral } \\
(3)\end{array}$ & $\begin{array}{c}\text { Disagree } \\
(2) \\
\end{array}$ & $\begin{array}{c}\text { Strongly } \\
\text { disagree (1) }\end{array}$ & Mean & $\begin{array}{l}\text { Std. } \\
\text { Dev. }\end{array}$ \\
\hline \multirow{2}{*}{$\begin{array}{l}\text { Is the use of } \\
\text { English as MOI } \\
\text { boring? }\end{array}$} & Freq. & 123 & 177 & 412 & 0 & 0 & \multirow[b]{2}{*}{3.81} & \multirow[b]{2}{*}{.719} \\
\hline & $\begin{array}{l}\text { Perc. } \\
(\%)\end{array}$ & 13.5 & 19.6 & 45.3 & 0 & 0 & & \\
\hline \multirow{2}{*}{$\begin{array}{l}\text { Is the use of } \\
\text { English as MOI } \\
\text { interesting? }\end{array}$} & Freq. & 107 & 114 & 421 & 0 & 0 & \multirow[b]{2}{*}{3.19} & \multirow[b]{2}{*}{.781} \\
\hline & $\begin{array}{l}\text { Perc. } \\
(\%)\end{array}$ & 16.7 & 17.8 & 65.5 & 0 & 0 & & \\
\hline \multirow{2}{*}{$\begin{array}{l}\text { Is the use of } \\
\text { English as MOI } \\
\text { alright? }\end{array}$} & Freq. & 207 & 481 & 15 & 0 & 0 & \multirow[b]{2}{*}{3.06} & \multirow[b]{2}{*}{.794} \\
\hline & $\begin{array}{l}\text { Perc. } \\
(\%)\end{array}$ & 29.5 & 68.4 & 2.1 & 0 & 0 & & \\
\hline \multirow{2}{*}{$\begin{array}{l}\text { Is the use of } \\
\text { English as MOI } \\
\text { very boring? }\end{array}$} & Freq. & 97 & 91 & 487 & 0 & 0 & \multirow[b]{2}{*}{2.98} & \multirow[b]{2}{*}{.802} \\
\hline & $\begin{array}{c}\text { Perc. } \\
(\%)\end{array}$ & 14.3 & 13.5 & 72.2 & 0 & 0 & & \\
\hline \multirow{2}{*}{$\begin{array}{l}\text { Is the use of } \\
\text { English as MOI } \\
\text { very interesting? }\end{array}$} & Freq. & 113 & 117 & 431 & 0 & 0 & \multirow[b]{2}{*}{3.04} & \multirow[b]{2}{*}{.796} \\
\hline & $\begin{array}{l}\text { Perc. } \\
(\%)\end{array}$ & 23.4 & 63.4 & 12.2 & 0 & 0 & & \\
\hline \multirow{2}{*}{$\begin{array}{l}\text { The English } \\
\text { language is for } \\
\text { people in Towns }\end{array}$} & Freq. & 115 & 127 & 401 & 0 & 0 & 2.04 & .896 \\
\hline & $\begin{array}{c}\text { Perc. } \\
(\%)\end{array}$ & 23.9 & 63.1 & 12.2 & 0 & 0 & & \\
\hline
\end{tabular}

The results in Table 2 revealed that out of the $61.9 \%$ of the respondents who claimed to be aware of MOI and its application in learning institutions of Muhanga district considering reference from section 4.3 the use of English as medium of instruction was given a varied perception and attitude with the MOI being boring" was ranked first (3.81), "the MOI being interesting" was ranked second (3.19), However "The English medium of instruction being alright" was ranked third (3.06), and on the contrary " the MOI being very interesting or being very boring were ranked fourth and fifth with means of (3.04) and (2.98) respectively. Thus, with regard to the findings, as much as the English medium of instruction is much acknowledged and perceived as MOI it is still facing challenges of acceptance and positive attitude from mainly learner and a minority of teachers.

The respondents were asked to provide their opinion on teachers' competences in relation to the use of English as MOI. The findings are illustrated in Table 3. 
Table 3: The Effect of Teachers' Competency and Curriculum Implementation in Primary Schools

\begin{tabular}{|c|c|c|c|c|c|c|c|c|}
\hline Statements & & $\begin{array}{l}\text { Strongly } \\
\text { agree (5) }\end{array}$ & $\begin{array}{l}\text { Agree } \\
\text { (4) }\end{array}$ & $\begin{array}{c}\text { Neutral } \\
\text { (3) }\end{array}$ & $\begin{array}{c}\text { Disagree } \\
\text { (2) }\end{array}$ & $\begin{array}{c}\text { Strongly } \\
\text { disagree (1) }\end{array}$ & Mean & $\begin{array}{l}\text { Std. } \\
\text { Dev. }\end{array}$ \\
\hline \multirow{2}{*}{$\begin{array}{l}\text { Do you mix English } \\
\text { and mother tongue } \\
\text { quite often when } \\
\text { teaching your subject } \\
\text { lesson? }\end{array}$} & Freq. & 17 & 85 & 13 & 0 & 0 & \multirow[b]{2}{*}{5.68} & \multirow[b]{2}{*}{.416} \\
\hline & $\begin{array}{l}\text { Perc. } \\
(\%)\end{array}$ & 14.8 & 73.9 & 11.3 & 0 & 0 & & \\
\hline \multirow{2}{*}{$\begin{array}{l}\text { Do you use } \\
\text { Kinyarwanda when } \\
\text { interacting with } \\
\text { colleagues during tea } \\
\text { and lunch breaks? } \\
\end{array}$} & Freq. & 17 & 94 & 4 & 0 & 0 & \multirow[b]{2}{*}{3.75} & \multirow[b]{2}{*}{.414} \\
\hline & $\begin{array}{l}\text { Perc. } \\
(\%)\end{array}$ & 14.8 & 81.7 & 3.5 & 0 & 0 & & \\
\hline \multirow{2}{*}{$\begin{array}{l}\text { Do you use French } \\
\text { when interacting } \\
\text { with colleagues } \\
\text { during tea and lunch } \\
\text { breaks? }\end{array}$} & Freq. & 17 & 97 & 1 & 0 & 0 & \multirow[b]{2}{*}{4.87} & \multirow[b]{2}{*}{.372} \\
\hline & $\begin{array}{c}\text { Perc. } \\
(\%)\end{array}$ & 14.8 & 84.3 & 0.9 & 0 & 0 & & \\
\hline \multirow{2}{*}{$\begin{array}{l}\text { Do you use English } \\
\text { when interacting } \\
\text { with colleagues } \\
\text { during tea and lunch } \\
\text { breaks? }\end{array}$} & Freq. & 17 & 91 & 7 & 0 & 0 & \multirow[b]{2}{*}{5.57} & \multirow[b]{2}{*}{.427} \\
\hline & $\begin{array}{l}\text { Perc. } \\
(\%)\end{array}$ & 14.8 & 79.1 & 6.1 & & 0 & & \\
\hline \multirow{2}{*}{$\begin{array}{l}\text { Do you use Kiswahili } \\
\text { when interacting } \\
\text { with colleagues } \\
\text { during tea and lunch } \\
\text { breaks? }\end{array}$} & Freq. & 210 & 590 & 110 & 13 & 0 & \multirow[b]{2}{*}{3.13} & \multirow[b]{2}{*}{.364} \\
\hline & $\begin{array}{l}\text { Perc. } \\
(\%)\end{array}$ & 23.1 & 64.8 & 12.1 & 1.4 & 0 & & \\
\hline \multirow{2}{*}{$\begin{array}{l}\text { Is the subject content } \\
\text { in the books easily } \\
\text { delivered in the } \\
\text { lesson? }\end{array}$} & Freq. & 213 & 590 & 110 & 0 & 0 & \multirow[b]{2}{*}{3.93} & \multirow[b]{2}{*}{.364} \\
\hline & $\begin{array}{c}\text { Perc. } \\
(\%)\end{array}$ & 23.4 & 63.4 & 12.1 & 0 & 0 & & \\
\hline
\end{tabular}

The revelation from results in Table 8 ranked the aspects of teachers' competences as follows; mixture of English and mother tongue while teaching was ranked first with mean of (5.68) and a deviation of (.416) from the central tendency. The use of English language while interacting with colleagues was ranked second (5.57) and a deviation of (.427) from the true mean, the use of French, Kinyarwanda and Kiswahili while interacting with colleagues were ranked third, fourth and fifth respectively with means of (4.87), (3.75) and (3.98). "The ease of delivering the subject content from the textbook" was rank sixth with (3.13). Thus, justifying the reasons why teachers use multiple languages interchangeably with the MOI to ensure that content if delivered with intended meaning to the pupils during the lesson and to others while interacting with fellow colleagues.

The results were triangulated with the interview results from the head teachers. One of the head teachers had this to say, "Use of English language is important and dominate 
in instructional process". However, another stated, "The use of other languages like using mother tongue is used to improve the understanding of concepts in English. For instance, explanations that demonstrate a certain English vocabulary word is common in the instructional process". Corroborated with observation schedule results, the chalk boards contained some English words elaborated and explained in mother tongue.

\subsection{Teaching Styles used by Teachers in Relation to the Use of English as Medium of Instruction}

The respondents were asked to provide information on the teaching styles they used in relation to the use of English as medium of instruction; the findings are illustrated in Table 4.

Table 4: Teaching Styles used by Teachers

in Relation to the Use of English as Medium of Instruction

\begin{tabular}{|c|c|c|c|c|c|c|c|c|}
\hline Statements & & $\begin{array}{l}\text { Strongly } \\
\text { agree (5) }\end{array}$ & $\begin{array}{l}\text { Agree } \\
\text { (4) }\end{array}$ & $\begin{array}{c}\text { Neutral } \\
\text { (3) }\end{array}$ & $\begin{array}{c}\text { Disagree } \\
\text { (2) }\end{array}$ & $\begin{array}{c}\text { Strongly } \\
\text { Disagree (1) }\end{array}$ & Mean & $\begin{array}{l}\text { Std. } \\
\text { Dev. }\end{array}$ \\
\hline \multirow{2}{*}{$\begin{array}{l}\text { Do you use Rote } \\
\text { Learning as method } \\
\text { of teaching your } \\
\text { subject lesson? }\end{array}$} & Freq. & 178 & 20 & 12 & 0 & 0 & \multirow[b]{2}{*}{5.88} & \multirow[b]{2}{*}{.333} \\
\hline & $\begin{array}{l}\text { Perc. } \\
(\%)\end{array}$ & 84.8 & 9.5 & 5.7 & 0 & 0 & & \\
\hline \multirow{2}{*}{$\begin{array}{l}\text { Do you use code } \\
\text { switching as method } \\
\text { of teaching your } \\
\text { subject lesson? }\end{array}$} & Freq. & 101 & 94 & 15 & 0 & 0 & \multirow[b]{2}{*}{5.41} & \multirow[b]{2}{*}{.803} \\
\hline & $\begin{array}{l}\text { Perc. } \\
(\%)\end{array}$ & 48.1 & 44.8 & 7.1 & 0 & 0 & & \\
\hline \multirow{2}{*}{$\begin{array}{l}\text { Do you use code } \\
\text { mixing as a method } \\
\text { of teaching your } \\
\text { subject lesson? }\end{array}$} & Freq. & 17 & 92 & 60 & 41 & 0 & \multirow[b]{2}{*}{5.95} & \multirow[b]{2}{*}{.263} \\
\hline & $\begin{array}{l}\text { Perc. } \\
(\%)\end{array}$ & 8.1 & 43.8 & 28.6 & 19.5 & 0 & & \\
\hline \multirow{2}{*}{$\begin{array}{l}\text { Does English subject } \\
\text { in your class } \\
\text { perform more } \\
\text { exemplary as } \\
\text { compared to other } \\
\text { subjects? }\end{array}$} & Freq. & 13 & 20 & 30 & 147 & 0 & \multirow[b]{2}{*}{5.71} & \multirow[b]{2}{*}{.503} \\
\hline & $\begin{array}{l}\text { Perc. } \\
(\%)\end{array}$ & 6.2 & 9.5 & 14.3 & 70 & 0 & & \\
\hline
\end{tabular}

From the findings in Table 4, the method of code mixing, was ranked first with mean of (5.95) followed by the use of rote learning (5.88), as the main teaching styles applied by majority of teachers in rural public primary schools in Muhanga district, Rwanda. However, code switching was ranked fourth with a mean of (5.41) and the English performance in comparison to other subjects was ranked third with mean (5.71) the deviation of the mean showed that code mixing, and rote learning contributes significantly to exemplary performance of English subject as compared to other subjects taught in primary schools in Rwanda. Their deviations were (.263) and (.333). The study findings depict Mayer's (2002) explanation of rote learning as a form of memorization, where the learner can only remember the concept but can hardly apply it in any situation 
or for problem solving skills. This could be implication for the challenges facing the use of English as a language a MOI.

The findings are triangulated with the interview with the head teachers. One of the head teachers had this to say, "While there are spelt out styles of delivery in various subjects in the schools, the teachers are at liberty to make choice of what they preferred". This implies that the intent to integrate ICT in teaching English is more effective if focused on teachers rather than the school management. The teacher choice of particular method of delivery means that they can easily be wooed into the use of ICT in teaching English. Another interviewee noted that the concern of integrating ICT in teaching English requires more attention to ease of use of the equipment among the teachers. Ensuring that the use of ICT in teaching English is easily adopted makes it a positive bias for teachers to adopt the various teaching styles.

\subsection{Likelihood of Use of Various Instructional Styles Related to Teaching English}

In another perspective, the subject teachers were asked to indicate the likelihood of use of various instructional styles related to teaching English in their class. The questionnaire item was measured Likert-scale using 1 - extremely unlikely, 2 - unlikely, 3 - neutral, 4 - likely and 5 - extremely likely. The collected data was analyzed and presented using Table 5.

Table 1: Likelihood of Use of Various Instructional Styles Related to Teaching English

\begin{tabular}{|l|c|c|c|c|c|}
\hline & Extremely unlikely & Unlikely & Neutral & Likely & Extremely likely \\
\hline $\begin{array}{l}\text { Participation in } \\
\text { the Learning Process }\end{array}$ & $9(7 \%)$ & $30(25 \%)$ & $23(19 \%)$ & $24(20 \%)$ & $31(26 \%)$ \\
\hline Relating to Experience & $14(12 \%)$ & $36(30 \%)$ & $34(29 \%)$ & $17(14 \%)$ & $16(13 \%)$ \\
\hline Create Learning Climate & $24(20 \%)$ & $40(34 \%)$ & $23(19 \%)$ & $11(9 \%)$ & $19(16 \%)$ \\
\hline Learner-Centered Activities & $11(9 \%)$ & $40(34 \%)$ & $32(27 \%)$ & $27(23 \%)$ & $7(6 \%)$ \\
\hline Personalizing Instruction & $13(11 \%)$ & $34(29 \%)$ & $21(18 \%)$ & $20(17 \%)$ & $29(25 \%)$ \\
\hline
\end{tabular}

Table 5 shows that the likelihood of use of various instructional styles relates to teaching English as MOI varied from the extremely unlikely to extremely likely. The extremely likely was the Participation in the Learning Process at 31(26\%) followed by personalizing instruction at 29(25\%). The most unlikely style to be used was create learning climate at $24(20 \%)$. The study findings have implications on the use of English as a MOI in the schools as various styles call different preference for teachers. The study findings are in line with Otaala's (2001) who posits that these methods and strategies should consequently be assessed across different aspects such as learning and teaching activities, the role of instructional materials and procedures.

Triangulation of the quantitative results with the interview results shows that the participation in learning process is the most significant pointers to adoption of ICT in teaching English. One of the headteachers had this to say, "ICT use in teaching English may have a variety of areas of application, However, the use of ICT and other instructional material to ensure improved participation in learning of the students is very critical". The emphasis is also 
noted in a number of studies which focus on making the learning environment interesting for learners. This helps in attracting their attention and hence improved participation.

\section{Recommendations}

The study recommends that the language of instruction, including local or indigenous languages and the English language, should be implemented in accordance with the provision in the National Education Policy in Rwanda. The effective implementation of English as the MOI in this regard is the responsibility of the Rwandan government, local stakeholders, and other international communities so that standards can be established and maintained. Any program for the effective implementation of MOI should give adequate attention to training and retraining of teachers, policy makers and primary school administrators / proprietors. Another recommendation is that both teachers and pupils should be exposed to appropriate and adequate instructional materials for using MOI, particularly in primary 4-6 classes. Teachers should be professionally trained on how to cope with English being the MOI as well as being proficient in the language.

\section{Conclusion}

The study concludes that the use of English as MOI has enhanced the curriculum implementation in rural primary schools of Muhanga district in the republic of Rwanda and is regularly applied in order to enhance academic performance. On teachers' competency, quality pre-service training and in-service training coupled with periodic review of qualification thresholds ensures that teachers are kept updated and in return enhances quality service delivery, and lastly in consideration of the teaching styles, the research findings concluded that proper use and management of rote learning, code switching and mixing of MOI and other languages coupled with "broken English" and mispronunciation will enhances proper use of MOI in curriculum implementation.

\section{Acknowledgements}

I wish to sincerely thank Dr. Ronald Kikechi who not only accepted to take over my work when I was transferred from Rwanda to Kenya on Medical grounds, but also for his constructive criticism and feedback, guidance and encouragement, which enabled me to accomplish my work. Many thanks go Mr. Jean Paul Harerimana, the dean of Education in Kigali Campus, who organized for my transfer and gave me maximum support enabling me to have a smooth transition. To the head teachers and teachers at the target schools, my interpreter Everegiste Minani, my two dear friends, Deborah and Elise who made sure I had a comfortable place to put up while in Kigali attending my lessons. To my mentors Mr and Mrs Litiku who believed in me and pushed me to aim higher. Above all and most important, all glory and honor go to God, Almighty who has brought me this far in all areas of my life. Indeed, He is Ebenezer. 


\section{Conflict of Interest Statement}

The authors declare no conflicts of interests.

\section{About the Author(s)}

Anne Nipher Olieba is an educator specializing in languages and curriculum studies. She has a passion for young people their learning and works as an instructional coach/ education advisor supporting teachers achieve competency in their teaching career.

Dr. Ronald Kikechi is the director, Mount Kenya University, Kakamega campus. He is a renown educationist with interest in educational management, administration and planning. He is also a consultant, an educational expert and researcher.

\section{References}

Andrews, S. (2011). Communicative Language Learning: Communicating for What Purpose? Modern English Teacher. 20(2), 5-12.

Barker (Eds), Policy and Practice in bilingual learning: A reader extending the Foundations (p.118-133). Clevedon, UK: Multilingual Matters.

Bennell, P. \& Ntagaramba, J. (2008) Teacher motivation and incentives in Rwanda: A situation analysis and recommended priority actions. Retrieved from http://www.rencp.org/wp-content/uploads. Teacher Motivation-and-Incentivesin Rwanda-08.Doc.

Brock-Utne B. (2007). Learning through a Familiar Language versus Learning through a Foreign Language: A look into some secondary school classrooms in Tanzania. International Journal of Educational Development. (27):487-498.

Brock-Utne, B. (1997). The Language Question in Namibian Schools. International Review of Education.1, (3) pp214-260. Netherlands: Kluwer Academic Publisher.

Collier, V. P. (1987). Age and Rate of Acquisition of Second Language for Academy Purposes. Tesol Quarterly. 21(4).pp.617-641

Brock-Utne, Birgit and Halmarsdottir, Halla (2003). Language policies and practices- Some preliminary results from a research project in Tanzania and South Africa. In: Brock-Utne, Birgit, Desai, Zubeida and Qorro, Martha, Language of instruction in Tanzania and South Africa (LOITASA) Dar-es-Salaam: E\&D Limited.

Gahigi, M. (2008). Rwanda English Language kicks off. Retrieved from http://allafrica.com/stories/200812010940.html.

Genishi, C. \& Dyson, A. (2009). Children, language, and Literacy: Diverse learners in diverse times. New York: Teachers College Press.

Hancock, R. D. \& Algozzine, B. (2006) Doing case study research: A practical guide for Beginning researchers. New York: Teachers College Press.

Holloway. I., \& Wheeler, S. (2002). Qualitative research in nursing (2nd ed.). Oxford U.K: Blackwell Science Ltd. 
Kajoro P. M. (2016). Transition of the Medium of Instruction from English to Kiswahili in Tanzanian Primary Schools. In: Halai A., Clarkson P. (eds) Teaching and Learning Mathematics in Multilingual Classrooms. Sense Publishers, Rotterdam

Kigali Institute of Education, (n.d.). Kagame reiterates need to use English as Education Medium; New Times. Retrieved from http://www.newtimes.co.uk.re/news/index.php.13684a.

Kigali Institute of Education (n.d). Faculty of Education (prospectus) Retrieved from http://www.kie.ac.rw/IMG/doc/PROSPECTUSEDUCATION-5doc.

Kwibuka, E. (2013). Speaking English becomes cool. Global: The International Briefing, Retrieved from http://www.global-biefing.org/current-issue. Literacy, Language and Learning Initiative FY13 - Q4 Quarterly Report (July - September 2013)

Malekela, George, A. (2003). English as a medium of instruction in post-primary education in Tanzania: Is it a fair policy to the learner? In: Brock-Utne, Birgit, Desai, Zubeida and Qorro, Martha, Language of instruction in Tanzania and South-Africa (LOITASA) Dar-es-Salaam: E\&D Limited

Mkwizu, M. (2003) Pedagogical Implications of using English as the Medium of Instruction in Teaching Civics in Tanzania secondary schools. (5) Oslo: Institute for Educational Research, University of Oslo.

MINEDUC (2008a) Nine Years Basic Education, Implementation Fast Track strategies. Retrieved from http://planipolis.iiep.unesco.org/upload/Rwanda/Rwanda 9 years basic.

MINEDUC (2011a). Annual Education Report 2010 featuring Nursery, Primary, Secondary, Literacy and Special Education GIA: Kigali.

Mosha, H. (2004). New directions in teacher education for quality improvement in Africa. Papers in Education and Development, 24,23-28.

Niyibizi, E. (2010). An evaluation of the Rwandan Trilingual Policy in some nursery and primary schools in Kigali City, (Unpublished doctoral dissertation): University of South Africa, Pretoria.

Nzitabakuze, C. (2011). Implementation of the English medium policy in Rwandan Primary schools: A case of Gasabo district, Rwanda. (Unpublished Master's thesis). Kenyatta University, Nairobi, Kenya.

Omolara, B. E. (2008). Pedagogical approaches to the teaching and learning of school Subjects in Africa in the 21st century. Institute of Education. Olabisi Onabanjo University, AgoIwoye Ogun State, Nigeria.

Orotho, A. J. (2002). Essentials of education and social science research methods: Qualitative and quantitative approaches. Nairobi: Acts press.

Patton, M. (2002). Qualitative Research Methods. (3rd Ed) London: Sage publications.

Pearson, P. (2014). Policy without a plan: English and medium of instruction in Rwanda. Current issues in Language Planning, 15:1.39-56.

Peterson, Rhoda (2006). The use of an African language as language of instruction at university level: The example of Kiswahili department at the University of Dar es Salaam in Tanzania. Oslo: Institute of Educational Research. 
Polit. et al. (2001). Research design. A review of features and emerging developments. In Adibiyi, J. Obisede, Abiyomi, T. Onnuga. European journal of business and management, ISSN2222-2839(online) 8(11).

Qorro, M. (2009). "Parents and Policy Makers" Insistence on Foreign Languages as Media of Education in Africa: Restricting Access to Quality Education - for whose Benefit? In: Brock-Utne, Brigit \& Skattum, I. (Eds) Language and Education in Africa: A comparative and Trans-disciplinary Analysis. Oxford.

The Republic of Rwanda, Ministry of Education (2004). The Language in Education Policy of the Ministry of Education, Science, Technology and Scientific research and an outline strategic plan for its implementation, Kigali, Rwanda: Author.

Republic of Rwanda, Ministry of Education, (2009). Teachers Service Commission baseline survey, Kigali, Rwanda: Author.

Republic of Rwanda, Ministry of Education (2010). Education Sector Strategic Plan 2012015. Rosendal, T. (2010). Linguistic Land shapes: A comparison of official and non-official language management in Rwanda and Uganda, focusing on the position of Africa languages. (Unpublished Doctoral Thesis) The University of Gothenburg, Germany.

Samuelson, B. L. \& Freedman, S. W. (2010). Language Policy, Multilingual education Power in Rwanda. Language Policy, 9(3).191-215.

Sibomana, E. (2006). A Sociolinguistic Analysis of the English Language use at the Kigali Institute of Education. (Unpublished BA Dissertation), Kigali Institute of Education.

Sibomana, E. (2015). The Roles of Kinyarwanda and English for High-Quality Education: New. Directions for the Future.

Makalela, L. (Ed). (2015). New Directions in Language and Literacy Education for Multilingual USAID (2012). Task Order 7: Early Grade Reading and Mathematics in Rwanda. Retrieved from: https://www.eddataglobal.org/

Uwambayinema, E. (2013). Science Teachers' challenges in implementing Rwanda's English as a medium of instruction Policy: A case study of Nyarugenge District secondary schools (Unpublished Masters' Thesis) California State University, Fresno, USA.

World Bank (2011). Rwanda: Education Country Status Report. Toward Quality Enhancement and Achievement of Universal Nine-Year Basic Education, an Education system in Transition: a Nation in Transition.

Yin, R. K. (2009). Case study research: Design and methods (4th ed). Thousand Oaks, CA: Sage. 
Creative Commons licensing terms

Author(s) will retain the copyright of their published articles agreeing that a Creative Commons Attribution 4.0 International License (CC BY 4.0) terms will be applied to their work. Under the terms of this license, no permission is required from the author(s) or publisher for members of the community to copy, distribute, transmit or adapt the article content, providing a proper, prominent and unambiguous attribution to the authors in a manner that makes clear that the materials are being reused under permission of a Creative Commons License. Views, opinions and conclusions expressed in this research article are views, opinions and conclusions of the author(s). Open Access Publishing Group and European Journal of Education Studies shall not be responsible or answerable for any loss, damage or liability caused in relation to/arising out of conflicts of interest, copyright violations and inappropriate or inaccurate use of any kind content related or integrated into the research work. All the published works are meeting the Open Access Publishing requirements and can be freely accessed, shared, modified, distributed and used in educational, commercial and non-commercial purposes under a Creative Commons Attribution 4.0 International License (CC BY 4.0). 